\title{
The wisdom of Ben Sira in MENA cultural context: A cultural topical index
}

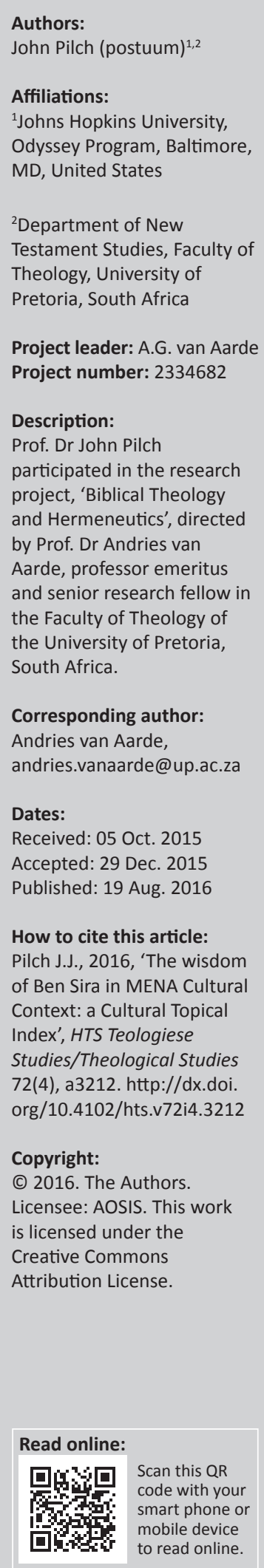

The biblical Books of Proverbs and Ben Sira (Sirach; Ecclesiasticus) yield no narrative continuity or logical outline. They are simply collections. The best way to interpret these books is with the aid of a topical index. Most topical indexes are based on English (or another language) translation. This article proposes a tentative topical index reflecting Middle East North African culture and its values. It will serve as the outline for a full length commentary already in process.

\section{Introduction}

Scholarly opinion about the structure of the Wisdom of Ben Sira (= Sirach; Ecclesiasticus amongst the Apocrypha in Protestant bibles) is divided. In general, scholars agree that it manifests a tripartite division found in the following chapters:

- 1-43 assorted instructions

- 44:1-50:24 praise of the ancestors in Israel

- two appendixes: 51:1-12 (gratitude to God), and 51:13-30.

At a more particular level, some scholars claim the book has a logical inner structure (Harvey 1993; Marböck 1997:61-79; Roth 1980). However, the majority would agree with Skehan and Di Lella (1987):

Except for chaps. 44-50, which in Cairo Hebrew MS B are appropriately entitled 'praise of the Ancestors of Old', the book manifests no particular order of subject matter or obvious coherence; hence only a descriptive list of topics, with some inevitable overlapping of classifications, can give an adequate impression of the contents of the book. (p. 4)

They then propose a meticulously specific list of topics, a topical index, to which we now turn our attention.

\section{A topical index}

Constructing a topical index for a biblical book, that seems to have no particular order of subject matter with obvious coherence, is challenging, but all the more so for the Wisdom of Ben Sira because of its complex manuscript tradition. Written originally in Hebrew around $175 \mathrm{BCE}$, then translated into Greek by Ben Sira's grandson, around $117 \mathrm{BCE}$, the Hebrew was lost until incomplete manuscripts were discovered between 1896 and 1900, 1931, 1956. Thus, currently more than two-thirds of the Hebrew is available. In general, the Hebrew texts agree substantially with the Greek. The best course, therefore, is to construct the topical index on an English translation (or translations) based on the evidence of all the ancient texts. In this article, we rely on the topical index proposed by Skehan and Di Lella, and review the Wisdom of Ben Sira texts according to the New Revised Standard Version with the Apocrypha. The Fully Revised Fourth Edition, 2010 (NRSV, notes by Daniel J. Harrington, S.J.) is compared to the New American Bible Revised Edition (NABRE 2011, dependent on Skehan \& Di Lella 1987).

Cynthia Miller's attempt to construct a topical index for Proverbs offers helpful guidance for constructing a topical index for the Wisdom of Ben Sira (Miller 2006:170-171). Firstly, she used the RSV as her basic text but indicated changes when the RSV emended the Hebrew. Secondly, because of Hebrew parallelism, she sometimes assigned the proverb to more than one topic if the subject in each stich was different. Thirdly, she did not include editorial headings (e.g., Pr 25:1; $30: 1 ; 31: 1)$. Curiously, however, her topical index has only three entries for 'honor' (Pr 22:1; 16:1; 27:21; see also 17:3), whilst a 'quick and dirty' concordance search turns up twenty occurrences of the word!

Note: Dr J.J. Pilch, John Hopkins University, Baltimore, USA, died on Friday 22 July 2016. 
Constructing a topical index on the basis of the English (or any other) translation, however, does not contribute to an understanding of the MENA ${ }^{1}$ cultural context of a given textsegment in the Bible. This would not help to understand what the Sacred Author wrote and intended for the original target audience. The topical index to the Wisdom of Ben Sira proposed by Skehan and Di Lella (1987:4-7), whilst quite complete, is nevertheless similarly deficient, because it is based on the English translation and pays no attention to Ben Sira's life-setting in MENA culture. To use an example from information technology (IT), attending to the culture lifesetting of a text-segment requires that the researcher use the same 'mental software' used by the original author (Pilch 2015:146).

\section{Culture}

'Mental software', or culture, can be understood as the 'collective programming of the mind that distinguishes the members of one group or category of people from others' (Hofstede, Hofstede \& Minkov 2010:4-7). The author of the Wisdom of Ben Sira, Yeshua Ben Eleazar Ben Sira (Sir 50:27), had different 'mental software' than contemporary nonMENA readers of his book. Without appropriate accommodation to Ben Sira's mental software, the nonMENA reader is doomed to misunderstand and misinterpret what he proposed.

Mental software is the program that directs the operating system (=human nature) to achieve specific goals. All people share the same operating system (human nature), but it is programmed differently by culture, the mental software for the operating system. MENA mental software directs human nature to function physically and psychologically in a very specific way quite different from western or other mental software. It determines and shapes perception and interpretation. Thus, the mental software necessary for crosscultural understanding belongs to the category of communication software (for an example, see ArabBible 5.5 www.arabbible.com). However, communication software rarely if ever provides cultural information, the major component of mental software necessary for understanding the cultural life setting of biblical text-segments and reports. This is what we tentatively construct and propose in this article.

\section{'Praise of the Ancestors' (Sir 44:1-50:24)}

The text-segment known as the 'Praise of the Ancestors' or 'Praise of the Fathers' (Sir 44:1-50:24) is a good place to begin exploring a MENA cultural topical index because it is a sustained, sequential development of a topic: Israel's ancestors (Corley 2008:151-181; Mack 1985; Maertens 1956). The text-segment consists of the following:

\footnotetext{
1.Egyptian anthropologists recommend using the term 'Middle Eastern North African" (MENA) rather than 'cirum Mediterrantean' or 'Alder Easter North African' (MENA) rather than 'circum-Mediterranean' or other such descriptors. The advantage of the acronym is that it recognises diversity whereby culture is not shared way of life but rather 'a constellation of values, meanings, and practices unevenly distributed to its members' (Gregg 2005:6; Pilch 2013:88).
}

- a proem on the subject of fame (44:1-15)

- a lengthy catalogue of biblical heroes ('ancestors' 44:16-49:16)

- an extravagant praise of the High Priest Simon son of Onias, a recently deceased contemporary of Ben Sira $(50: 1-21)$

- a concluding prayer (50:22-24).

Scholars note that it was shaped by the Greek encomium whose purpose was to praise the virtues of human beings and the social institutions that embodied cultural values (Mack 1985). In the Greek encomium, these heroes were kings, military commanders, and athletes, who demonstrated the highest ideals and virtues of Greek life. In contrast, Sirach's heroes include:

- rulers [David and Solomon]

- persons renowned for valour [Joshua, Caleb, and the Judges]

- counsellors [Nathan, Isaiah, Jeremiah]

- seers [Samuel, Elijah, Elisha, Isaiah, Jeremiah, Ezekiel, and the Twelve Minor Prophets]

- resolute governors [Joseph]

- lawgivers [Moses]

- sages [Solomon and Job]

- framers of proverbs and pointed maxims [Solomon, Ben Sira]

- composers of melodious psalms [David, Temple singers]

- authors with lyric themes [Solomon, Hezekiah]

- stalwart, self-reliant persons [Abraham, Isaac, Jacob]

- persons at peace in their own estates [Job]' (Skehan \& Di Lella 1987:500-501)

- all 'godly people' (Hebrew: 'anšê h.esed, Sir 44:1a, 10a)

- people of covenant loyalty

- people of piety worthy of imitation.

Claudia Camp, who employs social scientific methodology in her biblical research and focuses especially on the MENA core cultural values of honour and shame, says of Mack's analysis of the 'Praise of the Ancestors': '... he defines glory in strictly theo-religious ways, without attention to the anthropological connotations so evident elsewhere in the book [Wisdom of Ben Sira]' (Camp 1997a:176). This can be said of most if not all attempts to construct a topical index of biblical materials. No attention is paid to the cultural context of the biblical author, his work, and the original audience. Too often, the Bible is read as immediately relevant and applicable to the reader's culture. Camp insists that any investigation of Ben Sira's work must take into account honour and shame as his key cultural matrix (Camp 1997b:170, n.37; more on this topic below). deSilva's analysis of the Wisdom of Ben Sira achieves this admirably and demonstrates the distinctive thrust this Sage gave to honour and shame in his cultural setting (deSilva 1996). From a MENA cultural perspective, the 'Praise of the Ancestors' witnesses to a key characteristic of ancient Israelite society, namely, its collectivist nature (see Pilch 2016, Reading Scenario: Collectivistic Society). This is a major element of the topical index for the Wisdom of Ben Sira. 


\section{Collectivism}

Ethnographic data in the Human Relations Area Files (HRAF) at Yale University have led anthropologists to conclude that ninety-percent of societies on the planet are collectivist in nature. Collectivism describes 'societies in which people from birth onward are integrated into strong, cohesive in-groups, which throughout people's lifetime protect them in exchange for unquestioning loyalty' (Hofstede et al. 2010:92). People learn their identity from their collectivistic society, rely on the group for all decision making (consensus), and experience strong interconnectedness with the whole group (Pilch 2015:149). Thus, whilst the 'Praise of the Ancestors' of Israel does present heroes to imitate, as scholars note (e.g., deSilva 1996:435;452), it especially highlights for the reader or listener the distinctly impressive characteristics of one's in-group, namely Israel. It stirs a strong sense of pride and stimulates an effective desire to be worthy of membership in this in-group.

The chief in-group of collectivistic society is the extended family (King \& Stager 2001:4-5). The individual perceives and understands self as embedded in others (e.g. Isaac, son of Abraham, Sir 44:22; Aaron, brother of Moses, Sir 45:6; etc.) and draws personal identity only in relation to these others who form the fundamental in-group, the extended family. These are 'dyadic' or 'other-oriented' individuals who depend on others to provide them with a sense of who they are. The extended family also includes friends and associates. Collectivism, therefore, should constitute a major division of a topical index for the Wisdom of Ben Sira.

\section{Honour and shame}

Scholars have noted and explored the central importance of the key MENA core values of honour and shame in Ben Sira. Camp observed that ' $\mathrm{t}]$ he concepts of honor and shame constitute an essential part of Ben Sira's ideological matrix' (Camp 1997a:171). These values are a component of MENA mental software that runs continually beneath the surface operations of the software, directing the operating system of MENA individuals to perceive reality always from this vantage point. Even when the words do not appear in a textsegment, the concepts are there functioning unreflectively but effectively. For this reason, Camp insists that any reading of Ben Sira must attend to this fundamental matrix or conceptual field (Camp 1997b:170, n. 37). Although she urges that it must be not be applied woodenly to any topic under consideration, it really does permeate the Sage's perception so thoroughly that it can and should indeed be validly applied throughout his book in every case. The word 'glory' appears in translation more often than 'honour', but the meaning is the same.

\section{Topical MENA Cultural Index for the Wisdom of Ben Sira}

Because of its thoroughness, the topical index for the Wisdom of Ben Sira proposed by Skehan and Di Lella can be modified to reflect an interest in MENA cultural values (Skehan \& Di Lella 1987:4-6). What follows is the modified topical index.

\section{Honour and shame:}

a. Fear of the Lord - the basis for true honour: 1:1-30;

4:11-19;

6:18-37;

$16: 24-17: 23$;

19:20-30;

24:1-29;

25:3-6, 10-11;

b. Honour and shame:

4:20-6:4

10:19-11:6

37:16-26;

$41: 14-42: 8$

c. Honour for Wisdom's Author, God the creator: 39:12-35;

42:15-43:33.

d. True honour and the Service of God:

2:1-18;

7:29-31;

10:19-11:6;

17:24-18:14;

23:27;

32:14-33:15;

34:14-35:26.

e. Prayer that God display divine Honour and Glory 36:1-22.

f. Personal Honour: Autobiographical References 24:30-34;

33:16-19;

34:9-13;

39:12-13;

50:27;

51:13-30.

g. The Honourable Wise Person:

3:29;

14:20-15:10;

20:1-31;

21:11-24;

38:24-39:11.

h. Honour, wealth, and poverty

10:30-11:6, 14

11:10-11, 14, 18-19, 23-28;

13:15-14:10;

25:2-3;

26:28-27:3;

31:1-11.

i. Enjoying life honourably 14:11-19.

j. Honourable giving and repaying loans 29:1-7, 14-20.

k. Honourable name and reputation 41:11-13.

1. Honourable behavior 42:1-8.

\section{Values: honourable and shameful:}

a. Humility:

3:17-24;

$4: 8$;

7:16-17;

10:26-28. 
b. Charity (almsgiving):

3:30-4:6, 8-10;

7:32-36;

12:1-7;

29:8-13.

c. Virtues and vices of the tongue:

5:9-6:1;

$7: 13$

19:5-17;

20:5-8, 13, 16-20, 24-31;

22:6, 27-23:4, 7-15;

27:4-7;

28:12-16.

d. Pride, folly, sin in general:

3:26-28;

10:6-18;

11:6;

16:5-23;

20:2-31;

21:1-22:2, 18;

25:2;

27:12-15, 28 ;

33:5;

35:22-24;

41:10.

e. Anger, malice, vengeance:

11:22-24;

27:22-28:11.

f. Evil desire (unruly passions):

6:2-4;

18:30-19:4;

23:5-6, 16-26.

g. Other virtues and vices:

4:20-31;

5:1-8;

7:1-15;

8:1-19;

9:11-10:5, 29 ;

11:7-22;

15:11-20;

18:15-29;

25:1, 7-11;

27:8-21;

$34: 1-8$.

h. Frugality

29:21-28.

i. Health and healers

30:14-20;

38:1-15.

j. Death

38:16-23;

41:1-4.

k. Joy and pleasure

30:21-27;

40:1-27.

1. Manners and self-control at table 31:12-32:13; 37:27-31.

m. Household management

7:20-22;

33:19-33. n. Travel

34:9-12.

o. Begging

40:28-30.

\section{Collectivism}

'Praise of the Ancestors' Ben Sira 44:1-50:21 (and throughout).

\section{In-group: extended family:}

a. Parents

3:1-16;

7:27-28;

23:14;

41:17.

b. Children

7:23-25;

16:1-4;

22:3-4;

25:7;

30:1-13;

41:5-10.

c. Women (including wife and daughters)

7:19, 24-26;

9:1-9;

19:2-4;

22:3-5;

23:22-26;

25:1, 8, 13-26:18;

33:20;

36:26-31;

40:19, 23;

42:6, 9-14

d. Friends and associates (part of the extended [fictive] family)

6:5-17;

7:18; 9:10;

11:29-34;

12:8-13:23;

22:19-26;

27:16-21.

33:6;

36:23-25;

37:1-15.

\section{Conclusion (50:22-51:30)}

1. Epilogue: $50: 22-29$

2. Song of Praise: 51:1-12

3. Alphabetic Canticle: 51:13-30.3.

This tentative MENA cultural topical index serves as the guide and outline of my forthcoming cultural commentary on the Wisdom of Ben Sira. In the allotted space that remains for this article, I highlight specific cultural insights that can be gleaned from Ben Sira's work. As Camp has noted above, most interpretations of Ben Sira are 'theo-religious' with little to no acknowledgment of the cultural anthropological information embedded in his work. I will focus on the extended family and friends as reflective of the collectivistic character of ancient Israel. 


\section{Extended family}

As noted above, the extended family rather than the biological family is the most important in-group in a collectivistic society such as ancient Israel (King \& Stager 2001:4-5). There was a three-tiered structure of nested households:

- the house of the father (Gn 24:7; Js 2:12, 18; 6:25) with a huge and varied membership

- the tribal kingdom in which the King was head of the 'family'

- at the top was Yahweh, the supreme patriarchal authority over the sons of Israel who were bound to him through covenant.

This is in stark contrast with western individualistic culture in which the ties between individuals are loose: everyone is expected to look after him- or herself and his or her immediate 'family' (Hofstede et al. 2010:92). Ben Sira offers insightful comments on parents, children, women and friends. Friends are included in the notion of extended family because they generally have a life-long association with a family.

Many studies of the family in ancient Israel reveal a wealth of significant information (e.g., Cohen 1993; King \& Stager 2001:36-62; Perdue, Blenkinsopp, Collins \& Meyers 1997). However, insight about MENA culture and its values is meager and more often simply lacking. A review of Ben Sira's reflections from this point of view supplements that information.

\section{Parents}

In Ben Sira 3:1-16, Ben Sira essentially repeats God's commandment with its promise of long life for obedience (Ex 20:12; Dt 5:16). This repetition (also frequent in Proverbs) suggests that the commandment was often violated. Whilst on the surface the exhortation to 'serve parents as one's masters' (v. 7) sounds as if children were viewed as slaves, that would not be entirely incorrect. A certain aspect of 'servitude' does colour the relationship (see Pr 29:15, 17, 19). As Ben Sira 7:27-28 points out, children should repay their parents with love, honour and care, but it will be in a context of fear. In collectivistic culture where bonds between family members are strong and close, 'The glory of one's father is one's own glory, and it is a disgrace for children not to respect their mother' (Sir 3:11). To neglect one's father and demean one's mother blasphemes and provokes God, in whose stead parents stand. Sensitivity for one's reputation and the family's reputation (=honour) urges an offspring to avoid bringing shame on the family. The shame of one shames all. Thus, don't behave like a fool in public and disgrace one's upbringing, which would be a shameful reflection on one's parents (Sir 23:14). Most of all, avoid immorality (Sir 41:18) for there are no secrets in collectivistic society (Sir 9:6; 18:3-32; 19:2-4; 23:16-21). Everyone's life is a wide open book which drives people to resort to secrecy, deception, and outright lying intended to shield shameful and damaging truth from the prying eyes of others (Pilch 2016, Reading Scenario: Lying).

\section{Children}

Bible readers are quite likely aware of the hazards posed by inclusive language translations such as the NRSV. Whilst it makes the text pleasing to the contemporary reader from a non-MENA society, it misrepresents and distorts the intention and understanding of the Sacred Author in the MENA cultural context. 'Children' in Ben Sira 7:23 is literally 'sons.' 'Discipline' is physical and often severe (see Sir 30:1-3, 13; Pr $13: 24 ; 19: 18 ; 22: 25 ; 23: 13-14 ; 29: 15,17)$ and is restricted to sons who must learn manliness. Until the age of puberty, boys are raised with the girls by all the women with little to no influence from the father or other men. When at the age of puberty they enter the world of men, they have until then been pampered and sissified and must now learn how to be a male. The father must be able to reliably expect loyalty from the son and ready obedience. He does this by imparting severe physical discipline as necessary.

The father's task with daughters is to safeguard and guarantee their physical (sexual) integrity (literally 'guard their flesh'; Sir 7:24). The shame of failure in this obligation stains the entire family and requires that the daughter be executed. If successful, however, the father will be able to arrange a good marriage for her. Although the traditional partner for the daughter should be a paternal (or maternal) parallel cousin, the mother (who makes the arrangement) and the father (who publicly announces it) are able to manipulate the match so as to select a 'sensible' or intelligent groom (Sir 7:25).

Ben Sira resumes his reflections on daughters later in his book (Sir 42:9-14). The Sacred Author is too often reprimanded for the allegedly chauvinistic and misogynistic sentiments expressed in this text-segment. Keeping in mind the core MENA cultural value of honour, and the special obligation the head of the household, the patriarch, has in maintaining family honour (for a breach by one member stains the entire family and its reputation), the verses rather express genuine concern for this most valuable of all possessions: family honour and reputation. As marriages are arranged, what is the origin of the fear 'that she may not marry?' (v. 9). The matchmaker may consider her an undesirable match if her character or personality are not congenial. She may pass her over in favour of another partner. If disliked when she is married, the girl runs the risk of being divorced by her husband (Dt 23:13-21). She would have to return to her family home, they would have to forfeit the bride-price, and an endless feud would erupt with the potential for violence and bloodshed.

An unmarried woman who becomes pregnant is also a serious concern (v. 10). This would imply the failure of the males in her family (father and brothers) to protect her. The penalty, of course, is death, which is the only way to remove the stain of shame from the family. These are known as 'honour killings', and they have a long history in MENA cultures even to the present day (Pilch 1997:306-307). 
Even within the close confines of peasant villages where everyone minds everyone else's business, infidelity does occur. One can never know this for certain. The Torah presents a process by which a suspicious husband can explore his wife's fidelity or lack of it (Nm 5:11-31; see Sir 42:10). On the other hand, a married woman who has no children had a difficult life (1 Sam 1:1-28). Ben Sira concludes his reflections by urging fathers to keep a strict watch especially over a daughter lest she expose her father to ridicule amongst his fellows and become a topic of widespread gossip. Although the imagery of a moth coming from garments is erroneous, the idea that older women train the younger ones in devious and sometimes wicked ways is quite correct (Pr 31:2 reflects a mother's knowledge of how she trained her daughter). Ben Sira's concluding comment (v. 14a) expresses bitter frustration (perhaps from personal experience), although the entire verse is quite difficult to translate. 'Better is the wickedness of a man than a woman who does good; it is woman who brings shame and disgrace' NRSV); 'Better a man's wickedness that a woman's goodness, but better a religious daughter than a shameless son' (Skehan \& Di Lella 1987:478); 'Better a man's harshness than a woman's indulgence, a frightened daughter than any disgrace' (NABRE).

Thus, despite the parents' best efforts, some children turned out to be wicked and ungodly (Sir 16:1-4). Although in general, many children were considered a blessing (Gn 12:2; 15:5; 22:17; 24:60; Dt 28:4; Ps 127:3-5; 128:3-4; Sir 40:19a), Ben Sira cautions that it is better to die childless than to bear many wicked or ungodly children, that is, children who do not have the fear of the LORD (see also Sir 22:3-4). Blessed is the man who can rejoice in his children (Sir 25:7).

The main way to enhance the possibility of having one's sons turn out well is to discipline them: 'whip him often' (Sir 30:1), 'bow down his neck in his youth, and beat his sides whilst he is young' (Sir 30:12). As already mentioned, having been reared with the girls by all the women who pamper and spoil him (e.g., 2 Macc 7:27, boys are nursed for three years - twice as long as girls), the boy enters the harsh male world at puberty totally unprepared for the challenges that await him. Thus, Ben Sira urges the father to apply severe disciple so that he 'may rejoice at the way he turns out' (Sir 30:1). If successful, the son will be like the father (Tobit 7:2,7). He will be an avenger, a redeemer, one who redresses attacks on the family (Ps 127:5; Nm 35:12; Lv 25:25). If, however, the father spoils his son, or neglects to discipline him, the father will have 'sorrow of soul' and 'be offended by his shamelessness' (Sir 30:12-13; see Pilch 1993).

On the other hand, some fathers are indeed 'sinners ... ungodly ... for they have forsaken the Law of the Most High God' (Sir 41:5-10). Ben Sira refers here to those Israelites who abandoned the traditions of their ancestors and adopted pagan Greek practices and customs. They succumbed to the allure of the Hellenistic life style. Ben Sira recognised some value in Hellenistic culture, but as a conservative teacher he urged fidelity to the Israelite traditions. This was the aim of his teaching.
Ben Sira explicitly admits the collectivist nature of his culture when he writes: 'Children curse their wicked father for they suffer disgrace because of him' (Sir 41:7, NABRE). In collectivist society, all share a common lot. The children are tainted by the character of their father, no matter what their individual status might be. They derive their identity from the group, the family, and notably the patriarch.

\section{Women (including wives and daughters)}

Many scholars accuse Ben Sira of misogyny, even whilst admitting that his judgments reflect the attitudes of MENA culture towards women as it was in the past and continues so in many ways. Although writing about contemporary Muslim women, Abu-Lughod's caution is worth keeping in mind to avoid making ethnocentric and anachronistic evaluations of the past. She urges resisting the tendency to stereotype, 'to typify cultures through social scientific generalisations' ... '[which] prevents us from appreciating or even accounting for people's experiences' (Abu-Lughod 2013:6; revisiting ideas first published in 'Do Muslim Women Need Saving?' American Anthropologist 104, 2002:783-790).

From one point of view, the apparent misogynistic statements in the Bible could be viewed as a male expression of fear. They know that women actually make things happen: women are committed to purposeful activity (Pr 31:10-31), whereas men spontaneously - and often unwisely - react to events after they have occurred and nothing can be attempted to change the circumstances (Pilch \& Malina 2009:xxv). Men know they will always lose to the women, women will have their way (e.g., Gn 21:8-14; Judges 14-16). They do indeed wield power but in a different way to men.

This helps explain Ben Sira's list of cautions in 9:1-9. The cultural explanation for these warnings about the dangers posed by women (wives of others, prostitutes, etc.) lies in the simple fact that man often loses self-control. MENA culture does not condemn loss of self-control. It is expected and accepted that people move easily and readily from equanimity to loss of self-control (Fabian 1983:160-161). Passion aroused by the mere sight of a woman can be 'kindled like a fire' (v. 8d; see Job 31:9, 12). A wise man will strive to retain his self-control in all trying circumstances. However, if he loses self-control (Sir 19:2-4), it is expected that someone (relative, friend) will intervene before the experience turns violent with the potential of bloodshed. Ben Sira focuses on some of these threatening consequences: losing inheritance through dalliance with a prostitute (v. 6b), dying at the hands of an aggrieved husband or family redeemer (v. 9d).

As many have noted, Ben Sira reflects typical MENA attitudes toward women. Abu-Lughod, however, cautions against calling this misogynistic or chauvinistic, or inappropriate ethnocentric terms to describe 'the other' (see Fabian 1983). Interpreters of the Bible ought to explain what the Sacred Author wrote and what he meant and resist the temptation to please contemporary western (or other non-MENA) sensitivities. Ben Sira 22:3-5 provides just such an opportunity. 
Ben Sira criticises both an unruly (undisciplined) son (v. 3) and an impudent daughter (NABRE: 'hussy'; v. 5). They bring shame and disgrace to the father (and husband), which in the collectivistic view affects the entire family. The family's honour rating is destroyed, thus, the father is not so much concerned about his personal standing as he is about the welfare of the family. Just as lazy sons are excoriated in Proverbs for the damage they do to the family, so too are shameless sons and daughters in this instance.

The jarring statement in v. $3 \mathrm{~b}$ is translated in various ways: 'birth of a daughter is a loss' (NRSV); 'she brings him to poverty' (NABRE); 'she was born for his disrepute' (Skehan \& Di Lella 1987, 307-308). These renditions reflect the Syriac translation (4th century A.D.) which takes the Hebrew word hesed in a pejorative sense. The meaning of the translations, however, is the same. The statements reflect Judaic sentiment of that period. The Babylonian Talmud reports: 'It was taught: R. Judah used to say, A man is bound to say the following three blessings daily: [Blessed art thou...]' '...who has not made me a heathen [Gentile]', '... who has not made me a woman' '... who hast not made me a brutish man [slave].' (Menahoth 43b).

The loss can be understood thus: When her marriage is arranged, the daughter moves to her husband's family and lives in the Patriarchal compound. Her family has lost a valuable pair of working hands. Even if the bride-price is significant, this loss has an impact on the family. Possibly it could make the family even more poor than it already is, certainly in status if not also financially. 'Born for disrepute' may be harsh and overly judgmental. The risk is there, no doubt (see Sir 42:9-14). As a father plays no role in rearing the daughter (or the sons before puberty), there is nothing he can do but hope for the best. He is fortunate if the daughter, as raised by her mother and all the women, is sensible (v. 4). It will be easier to arrange a good marriage for her. But a shameful daughter will disgrace her father and her husband.

Echoing the common view in the Wisdom tradition, Ben Sira condemns adultery and repeats the penalty assigned for it in the Israelite tradition (Sir 23:22-25). He focuses on the woman. NRSV states that 'she has committed adultery' (v. 23c). NABRE and Skehan and Di Lella simply term her behaviour 'wanton adultery' (Skehan \& Di Lella 1987:320). The translation and interpretation is somewhat misleading. By definition, in MENA culture adultery is a deed by a male that actively impugns the honour of another male by means of his embedded women (wife or wives; Malina 2001:149). It not only dishonours a man but his family honour as well. It is extreme and total dishonour with no possible revocation. This is a first degree challenge, and requires a first degree response: murder. Strictly speaking by this definition, a woman can't commit adultery. She is, of course, a partner in the deed, and sometimes may even actively promote the opportunity - mainly to shame the husband. It's a woman's way of getting revenge. Such behaviour on the part of the woman indicates a lack of shame, that is, a lack of sensitivity to her honour and that of the family. Being a willing partner in adultery, of course, results in her being shamed.

In the post-exilic period, adultery is not only an outrage to male honour but also an abomination to the LORD ( $\mathrm{Lv}$ 18:20, 29; 20:10; Ezk 22:11). The phrase 'abomination to the LORD' describes improper deeds although not necessarily violations of the Mosaic law as in Deuteronomy (see Pr 3:32; 6:16; 11:1, 20; 12:22; 15:8, 9, 26; 16:5; 17:15; 20:23). Nevertheless, such deeds are displeasing to God.

NRSV 'leaves her husband' is unimaginable in MENA culture. Such a woman would be killed by her husband or her own male relatives. The actual sense is 'to be unfaithful', and the implication here is that she willingly consented to the adultery. Given the small population of villages (in which all are related), the nosey tendency of peasants, and lack of opportune space, it is difficult to imagine a scenario for adultery, but it did indeed happen. Ben Sira's concern is the child of the adultery. It is now an heir with a legitimate claim on the patriarchal patrimony (Judges 11:1-2). However, the matter becomes complicated because an illegitimate child was not considered as belonging to the congregation of Israel. In this case, the illegitimate child and the inheritance complications are the woman's fault because she appears to have taken the initiative in this risk. Ben Sira gives three reasons why the woman should be punished. She broke God's law (Exod 20:14; Deut 5:18), betrayed her husband, and bore a child by a man other than her husband. For this reason, she should receive the traditional punishment: summoning before the assembly for publish punishment (this would most likely be scourging [Pr 6;32-33], as death by stoning [Lv 20:10; Dt 22:22-24; Ezk 16:36-40] was apparently not enforced in Ben Sira's time). Moreover, the husband was required to divorce her, and she forfeited all her property rights stipulated in the marriage contract. The child was denied membership in the congregation of Israel, or membership was seriously in doubt.

Ben Sira devotes some lengthy reflections to the topic of wives and husbands (Sir 25:1, 8; 25:13-26:18; 36:26-31). Whilst reading these, it is important to keep in mind the MENA cultural customs regarding marriage. To begin with, marriage is the fusion of the honour of two families represented by two individuals. It is arranged; the partners are not self-selected. Typically the partners are parallel cousins (either patrilineal or matrilineal). As women raise the boys and girls together from birth (to puberty for the boys), they know all the children (prospective partners) very well. Mothers (and all the women) decide the best match; fathers announce it to the public at the appropriate time. The mothers and other women are susceptible to persuasion - within limits - on the part of the prospective bride for a preferred mate. The choices, however, are restricted by the availability of male partners.

It is also important to recall the advice of the Queen Mother to her son, Lemuel: 'Do not give your strength to women, 
your ways to those who destroy kings' (Pr 31:3). [Ben Sira has similar advice with regard to son, wife, brother, and friend: Sir 33:20, whose context is financial resources]. She knows how she has trained her daughters, as all women raise their daughters. In MENA cultures, women are the agents, they make things happen. They are in charge (see Pr 31:10-31). They also learn how to manipulate men in order to have their way. Sarah (Gen 16:5-6; 21:9-14), Rebekah (Gen 27), Bathsheba (1 Kings 1-2), Esther, and Judith are just some of the women of the Bible who had their way with men. Men, of course, are aware of this threat. The allegedly misogynistic statements by men in the Bible (an ethnocentric judgment) are perhaps better viewed as male expressions of fear, knowing full well the inevitable consequence of their dealings with women (reflecting the actual emic, i.e., indigenous, situation).

On the positive side, Ben Sira is pleased when a husband and wife live in harmony (Sir 25:1), and the woman is sensible, good and loyal (Sir 25:8; 26:1-4, 13-18). Such a wife is a true 'gift from the Lord' (Sir 26:14), 'a supreme blessing' (Sir 26:15 NABRE). In Ben Sira 26:15b, Ben Sira praises the 'value of her chastity' (NRSV: 'no scales can weigh the worth of her chastity', NABRE: 'priceless her chaste person' [Skehan \& Di Lella 1987:345]). In contrast to his comments about adulterous women, this statement by Ben Sira expresses the security a husband feels when his wife is faithful, that is, when he has effectively been able to control her sexuality. These sentiments confirm a match well made.

On the negative side, his comments make one wonder whether they came from personal experience (Sir 25:13-26; 26:5-12, 22-27)? Heartache caused by a woman is the worst of all (Sir 25:13a; Gen 21:10-11). Polygamy and the inevitable clashes of rival wives are the subject of Ben Sira 25:14-15 (see also Sir 25:8b; 26:6a; 37:11a). When wives become enemies to each other and the husband - their clashes entail vengeance, they are like the venom of a snake. Living in such a context is unbearable. Keep in mind that husbands and wives did not actually occupy the same space. There were women's quarters, and places where only men could congregate. Even so, the unpleasant environment causes a man to wish he lived elsewhere (Pr 21:19; 25:24; 27:15).

Verses 17-23 focus on external appearances, both of the errant wife and the unfortunate husband. Ancient Israelites were not only non-introspective, but anti-introspective. Only God could read hearts; humans could only judge by external appearances (1 Sm 16:7). On the one hand, wickedness changes a woman's appearance. Likewise, Ben Sira warns his students not to be ensnared by female beauty or wealth. The result would be shame and disgrace - a depressed mind, saddened face and a broken heart. All of this and more will come from a woman who does not make her husband happy.

Ben Sira 25:24, by ascribing the origin of sin to a woman, misinterprets Gen 3:6 and the biblical tradition in general (Wis 2:23-24). Ben Sira's final word here is, if a husband is unable to control his wife, then he should divorce her (Sir 25:25-26).

Returning again to the topic of a good wife (Sir 36:26-31), Ben Sira adds further desirable qualities. His opening comment is somewhat puzzling: 'A woman will accept any man as husband, but one girl is preferable to another' (v. 26). MENA marriages are arranged; prospective partners have no choice in the match, although one or the other (prospective groom or bride) can try to sway the matchmakers to make a personally preferable choice (Gregg 2005:61). Jacob preferred the younger Rachel to her elder sister, Leah (Gen 29:15-20), but Laban compelled him to marry Leah first. Mediterranean anthropologists, of women, suggest that this passage reflects the myth of male dominance in MENA culture. Rather, it highlights the power of women in arranging the matches (Pilch 2007:146-147). A woman will accept any man as husband because the female matchmaker has acted in her best interest. Males are at the mercy of the female matchmakers, especially if the prospective bride is removed by some geographic distance, or is only distantly related to the male. Whilst the man may have a preference, he must accept what the matchmaker presents to him - perhaps in revenge, or with intent to harm the man.

The desirable qualities of a good wife are beauty (v. 27) and soothing speech (literally 'healing of tongue', see Pr 15:4a; NRSV 'kindness and humility' is based on the LXX). Such a wife is a husband's best possession, as she makes him more fortunate than other men as he has a fit helper and pillar of support (Gen 2:18). A devoted wife is better than wealth (cattle and orchards, Sir 40:19), and a sensible wife preferable to friends and neighbours (Sir 40:23). A woman without a husband is at risk of being ravished, whilst a man without a wife and home is restless, untrustworthy, unwelcome and unwanted wherever he may roam (vv. 30-31).

\section{Friends and associates (considered part of the extended [fictive] family)}

Friendship differs widely across cultures (Stewart \& Bennett 1991:100-103). For example, Americans are reluctant to form deep, long-lasting, dependent relationships. The ideal is the self-reliant person with no need of others outside the family. Even then, there is reluctance to depend on another family member. Americans compartmentalise friends (e.g., dining companions, partners in sporting activities, travel companions, etc.). Foreign visitors to the US are frequently frustrated by the American view of friendship and their reluctance to become involved with others, which is so starkly different from their indigenous experience (Althen \& Bennett 2003:128-131).

Friendship in MENA cultures, particularly ancient Israel, is a more intimate relationship. The Hebrew word for friend, 'ohēb, derives from the word for love indicating that the element of affection is prominent in this concept. People unrelated by blood form a relationship and establish a bond 
that is mutually intimate, loyal, and loving. Gregg (2005) observes:

Individuals in all MENA groups, thus, tend to be enmeshed in networks of kin that extend beyond their nuclear families, and the boundaries between kin and outsider tend to be blurred, fluid, and flexible. (p. 59)

The result is that the friend is considered part of the in-group, indeed, a member of the extended family. Friends are passed from father to son ( $\operatorname{Pr} 27: 10)$, in other words, they remain part of the family. Sometimes friends are even more faithful than one's blood relatives (Pr 18:24). The classical example of friendship in the Israelite tradition is the relationship between David and Jonathan (see 1 Sm 18:1-3; 20:17; 2 Sm 1:26). Of special significance is the relationship of God with humans. Abraham was identified as 'friend of God' (1 Chr 20:7) as too was Moses (Ex 33:11). The pain caused by cruelty or infidelity of a friend is proportional to the intimacy of the friendship (Ps 41:10).

Ben Sira offers his students a few reflections on friendship (Sir 6:14-17; 7:18; 9:10-16; 11:29-12:18; 19:13-17; 22:19-26; 27:16-21; 37:1-6; see Corley 2002). He treats the topic at greater length than any other Sacred Author. Ben Sira begins by noting the exceeding value of a friend (Sir 6:14-17): 'sturdy shelter', 'treasure', beyond price', 'incomparable worth', 'lifesaving medicine' (literally 'medicine of life'). Only those who fear God will find such friends (v. 17), a person like oneself who is diligent to observe the Law and please God. The broader context of this description offers advice about selecting and evaluating friends (Sir 6:5-13). The phrase in verse 6 'those who are friendly' is literally 'men of your peace' (see Ps 41:10; Jr 20:10; 38:22). The advice is rather self-evident but puzzling in the light of MENA cultural understanding of friends as described just above. Perhaps the context for this advice about caution and testing friends is the rapid infusion of Hellenism and its values in Ben Sira's Jerusalem. Some Israelites - to Ben Sira's dismay - were seeking to adopt Hellenstic ways and to make friends with these newcomers. His warning not to 'barter a friend for money' (Sir 7:18) would suit precisely such a situation. This cultural context would explain his reason for urging caution in making new friends, and his enumeration of the dangers of fickle and unreliable friends. Surely these are not family friends with roots in past generations, the typical Israelite cultural context. Hence, do not abandon old friends (Sir 9:10) who keep the law of the Most High and fear the LoRd (vv. 15-16).

Similar cautious advice appears in Ben Sira 11:29-12:18. Surely it must refer to 'new friends' in the Hellenistic milieu, perhaps Hellenised Israelites, who now are not to be trusted. They will strive to persuade you to abandon your heritage (Sir 11:34). These are not at all in the same category as the generations-long family friends. Such a scenario also helps to understand the references to 'sinners' (and 'enemies') in these verses (vv. 4, 5, 6, 7).

There are times when one must confront a friend (Sir 19:13-17). It has to do with gossip, which is rife in MENA cultures
(Pr 11:13; 20:19; Sir 17:16-21; 41:1; Rohrbaugh 2007:125-146). Should one hear gossip about a friend, it is worth determining whether the gossip is true or not. If true, admonish the friend lest he do or say it again; if not, then 'do not believe everything you hear' (v. 15). Above all, 'let the law of the Most High takes its course' (v. 17).

Related to gossip is the betrayal of trust or revealing a confidence (Sir 27:16-21). It is an integral element of loyalty and faithfulness (see below). Betraying trust is a definitive way of ending a friendship. Keeping in mind the MENA cultural context of friendship described above, a generations long affiliation with a family, it is easy to understand the grave damage caused by revealing a confidence, and betraying a trust. 'Whoever betrays secrets does hopeless damage' (v. 21 NABRE).

Clearly the confrontation and admonition spoken of in Ben Sira 19: 13-17 also has the potential for ruining a friendship (Sir 22:19-26). Reviling a friend or drawing a sword against him would surely threaten a relationship. However, reconciliation always remains possible. On the other hand, 'a contemptuous insult, a confidence broken, or a treacherous attack will drive any friend away' (v. 22cd, NABRE) and end a friendship. Ben Sira's advice to remain faithful to a poor friend in order to benefit when his lot improves is somewhat embarrassing to some readers because of its apparent pragmatism. This, however, is an ethnocentric reaction. The basic MENA cultural value behind Ben Sira's advice is loyalty, no matter what. It is a key MENA value particularly characteristic of friendship in this culture. Loyalty is more commonly spoken of in the Bible as faith or faithfulness (Pilch \& Malina 2009:72-75).

In a final comment on friendship (Sir 37:1-6), Ben Sira speaks of a friend who becomes an enemy, which is a cruel experience (Ps 41:10; 55:13-15). A good friend, in contrast, will remain faithful, loyal, and stand firm with you against all foes.

\section{Conclusion}

Whilst some scholars perceive an orderly and meaningful composition in Proverbs and Ben Sira, most view these books are simple collections with no discernible plan of organisation. For this reason, commenting on these books with the aid of a cultural topical index is best suited for highlighting the cultural values and understandings embedded in them. We have emended and revised the mainly 'theo-religious' topical index proposed by Skehan and Di Lella to construct a tentative MENA cultural topical index. In this paper, we have focused chiefly on Ben Sira's reflections on kinship and friendship as expressing collectivism, which is a major MENA cultural characteristic. The interpretations differ considerably from the majority of treatments which tend to view Ben Sira's wisdom as universally valid and applicable to all cultures. In this article we have attempted to highlight the distinctive MENA cultural values expressed by Ben Sira. 


\section{Acknowledgements Competing interests}

The author declares that he has no financial or personal relationships which may have inappropriately influenced him in writing this article.

\section{References}

Abu-Lughod, L., 2013, Do Muslim women need saving?, Harvard University Press, Cambridge, MA.

Althen, G. \& Bennett, J., 2003, American ways: A cultural guide to the United States, Intercultural Press, an imprint of Nicholas Brealey Publishing, Boston, MA.

Camp, C., 1997a, 'Honor and shame in Ben Sira: Anthropological and theologica reflections', in P.C. Beentjes (ed.), The book of Ben Sira in modern research, proceedings of the first international Ben Sira conference, Soesterberg, The Netherlands, July 28-31, 1996, pp. 171-187, Walter de Gruyter, Berlin.

Camp, C., 1997b, 'Honor, shame, and the hermeneutics of Ben Sira's Ms C', in M.L. Barré (ed.), Wisdom, you are my sister: Studies in honor of Roland E. Murphy, $O$. Carm., on the occasion of his eightieth birthday, CBQMS 29, pp. 157-71, Catholic Biblical Association, Washington, DC.

Cohen, Shaye J.D. (ed.), 1993, The Jewish family in antiquity, Brown Judaic Studies 289, Scholars Press, Atlanta, GA.

Corley, J., 2002, Ben Sira's teaching on friendship, Brown Judaic Studies 316, Brown University, Providence, RI.

Corley, J., 2008, 'Sirach 44:1-15 as introduction to the praise of the ancestors', in G.G. Xeravits \& J. Zsengeller (eds.), Studies in the book of Ben Sira: Papers of the third international conference on the deuterocanonical books, Shime'on Centre, Pápa, Hungary, May 18-20, 2006, pp. 151-181, Brill, Boston, MA.

deSilva, D.A., 1996, 'The wisdom of Ben Sira: Honor, shame, and the maintenance of the values of a minority culture', $C B Q 58,433-455$.

Fabian, J., 1983, Time and the other: How anthropology makes its object, Columbia University Press, New York.

Gregg, G.S., 2005, The middle east: A cultural psychology, Oxford University Press, Oxford.

Harvey, J.D., 1993, 'Toward a degree of order in Ben Sira's book', ZAW 105, 52-62. http://dx.doi.org/10.1515/zatw.1993.105.1.52
Hofstede, G., Hofstede, G.J. \& Minkov M., 2010, Cultures and organizations: Software of the mind. Intercultural cooperation and its importance for survival, Revised and Expanded 3rd edn., McGraw-Hill, New York.

King, P.J. \& Stager, L.E., 2001, Life in biblical Israel, Westminster John Knox, Louisville, KY.

Mack, B.L., 1985, Wisdom and the Hebrew Epic: Ben Sira's hymn in praise of the fathers, University of Chicago, Chicago, IL.

Maertens, T., 1956, 'L'Éloge des Pères (Ecclésiastique XLIV-L)', LumVie 5.

Marböck, J., 1997, 'Structure and redaction history of the book of Ben Sira: Review and prospects', in P.C. Beentjes (ed.), The book of Ben Sira in modern research. and prosings of the first international Ben Sira conference, Soesterberg, The Netherlands, July 28-31, 1996, pp. 61-79, Walter de Gruyter, Berlin.

Miller, C.L., 2006, 'Translating proverbs by topics', The Bible Translator 57, 170-194. http://dx.doi.org/10.1177/026009350605700402

Perdue, L.G., Blenkinsopp, J., Collins, J.J. \& Meyers, C., 1997, Families in ancient Israel, Westminster John Knox Press, Louisville, KY.

Pilch, J.J., 1993, "'Beat his ribs while he is young" (Sir 30:12): A window on the Mediterranean world', Biblical Theology Bulletin 23, 101-113. http://dx.doi. org/10.1177/014610799302300303

Pilch, J.J., 1997, 'Family violence in cross-cultural perspective: An approach for feminist interpreters of the Bible', in A. Brenner \& C. Fontaine (eds.), A feminist companion to reading the Bible: Approaches, methods, and strategies, $\mathrm{pp}$ 306-323, Academic Press, Sheffield.

Pilch, J.J., 2007, Introducing the cultural context of the Old Testament, Wipf \& Stock Eugene, OR. Reprint with corrigenda of Introducing the cultural context of the Old Testament, 1991, Paulist Press, New York.

Pilch, J. J. 2015, 'Proverbs in MENA (Middle East North Africa) cultural context', Biblical Theology Bulletin 45, 144-154. http://dx.doi.org/10.1177/0146107915608594

Pilch, J.J., 2016. The cultural life setting of the proverbs: A social scientific analysis of the book of proverbs, Fortress Press, Minneapolis, MN.

Pilch, J.J. \& Malina, B.J. (eds.), 2009, Handbook of biblical social values, Baker Academic, Grand Rapids, MI.

Rohrbaugh, R.L., 2007, 'Gossip in the New Testament', in R.L. Rohrbaugh (ed.), The new testament in cross-cultural perspective, Wipf \& Stock, Eugene, OR, pp. 135-146.

Roth, W., 1980, 'On the gnomic-discursive wisdom of Jesus Ben Sirach', Semeia 17, $59-79$.

Skehan, P.W. \& Di Lella, A.A., 1987, The wisdom of Ben Sira, AB 39, Doubleday, New York.

Stewart, E.C. \& Bennett, M.J., 1991, American cultural patterns: A cross-cultural perspective, rev. edn., Intercultural Press, Yarmouth, ME. 